\title{
Measurement of Comparison to Scattering Dose Space According to the Presence or Absence of Protective Clothing in the X-ray Room
}

\author{
Yeji Heo*, Kyotae Kim*, Changhoon Cho*, Suman Kano", Jikoon Park", \\ Sangsik Kang*, Sicheul Noh* ,Bongjae Jung* \\ Department of Radiological Science, International University of Korea, \\ Department of Radiation Oncology, Kosin University Gospel Hospital ${ }^{\text {** }}$
}

\section{$\mathrm{X}$ 선 촬영실에서 방호복 유무에 따른 공간산란선량의 측정 비교}

\author{
허예지*, 김교태*, 조창훈*, 강수만**, 박지군*, 강상식*, 노시철*, 정봉재* \\ 한국국제대학교 방사선학과*, 고신대학교 방사선종양학과**
}

\begin{abstract}
Current medical institutions with the development of medical technology to the increased demand for health use of radiation equipment is increasing rapidly. Direct radiation from the patient receives the aim of reducing exposure as much as possible is important and the spatial dose of scattered radiation with in the space to engage in reducing healthcare physician, radiation workers and carers need to reduce indirect exposure. X-ray radiation workers and caregivers in the $\mathrm{X}$-ray room to wearing of protective clothing is advised. However Radiation worker sand caregivers of patients with secondary is done, by wearing protective clothing to wear protective clothing because of the weight and discomfort have been neglected.

In this study, based on the presence or absence of clothing scattered radiation from space to measure distances, depending on the horizontal and height by measuring the angle of the importance of wearing protective clothing were investigated.
\end{abstract}

Key Words: Radiation equipment, Scattered radiation from space, Radiation worker, Caregivers, Protective

\section{요야}

현재 의료기관은 의학 기술의 발전과 더불어 건강에 대한 관심이 고조됨에 따라 방사선 발생장치의 이용이 급증하 고 있다. 방사선으로 인해 환자가 받는 직접적인 피폭을 가능한한 줄이는 목적도 중요하지만 촬영시 공간 내에서 받을 수 있는 간접적인 피폭을 줄여 의료업에 종사하는 의료인, 방사선 작업종사자 및 보호자의 피폭을 줄여야 한다. 엑스선 촬영실에서는 방사선작업종사자 및 보호자에게 방호복의 착용을 권고하고 있으나 불가피하게 방사선작업종사자 및 보 호자가 환자의 촬영 보조를 할 경우, 방호복 착용에 의한 중량감 및 불편함 때문에 방호복 착용이 등한시 되고 있다. 이에 본 연구에서는 방호복 유무에 따라 공간산란선량을 측정하고 거리, 가로면 각도 및 높이에 따라 측정함으로써 방 호복 착용의 중요성을 알아보고자 하였다.

중심단어: 방사선발생장치, 공간 산란선량, 방사선작업종사자, 보호자, 방어. 


\section{I. 서론}

1895년 뢴트겐이 X선을 발견한 이후 공학, 의학 분 야에서 X선 사용이 증가하고 있으며 ${ }^{[1]}$ 이에 따라 현대 의학 기술도 발전하게 되고 임상 의학적인 진단을 위 해 방사선의 사용이 필수화 되고 있다. X선 발견 초기 에는 많은 방사선 작업종사자들이 방사선 장해를 입 게 되면서, 사람들은 방사선 피폭에 대한 위험성을 인 식하게 되었으며 방사선 피폭을 저감화하기 위하여 국제 방사선 방어위원회(International Commission on Radiological Protection, ICRP)를 설립하고 권고안을 제 시하였다 ${ }^{[2]}$.

최근에는 일본의 원전사고와 고리원자력발전소의 미흡한 대처 때문에 방사선에 대한 관심이 어느 때 보 다 높게 나타나고 있어, 방사선을 취급하는 방사선작 업종사자의 역할이 중요한 시기라고 볼 수 있다. 이러 한 시점에 의료기관에서 많이 사용하고 있는 방사선 발생장치의 경우 환자의 진단검사에 이용되고 있으며, 대부분 방사선사가 취급하고 있기 때문에 안정적인 방사선관리가 이루어지고 있다고 볼 수 있으나, 방사 선에 대한 관심이 어느 때 보다 높은 이 시점에 방사 선검사시 발생하는 공간선량과 방사선피폭에 대한 이 해가 필요한 때라고 볼 수 있다.

방사선으로 인한 피폭은 내부피폭과 외부 피폭으로 구분할 수 있으며 외부 피폭에서는 간접적인 피폭과 직접적인 피폭으로 나뉜다. 방사선 작업 종사자 및 보 호자는 간접적인 피폭을 주로 받으며 이는 공간 산란 선량으로부터 발생하는 피폭으로, 최근 식품의약품안 전청 연구 조사에 따르면 다른 직종에 비하여 방사선 작업 종사자가 적게는 4 배에서 많게는 24 배까지 더 많 은 피폭을 받는 것으로 조사되었다 ${ }^{[3]}$.

이러한 외부 피폭에 대한 저감화 방안으로는 시간, 거리, 차폐의 3 원칙으로 규정하고 있다. 방사선 장해를 최소화 하기 위해서는 반드시 3원칙을 고려해야하며, 거리와 시간을 불가피하게 이행 할 수 없을 경우에는 방사선 발생장치와 방사선작업종사자 사이에 적절한 차폐물을 설치하여야한다. 따라서 직접적인 피폭을 가 능한한 줄이는 목적도 중요하지만 간접적으로 발생하 는 공간 산란선량을 줄여 피폭을 줄이고, 그로 인한
방사선 장해를 저감화 하는 방안을 마련해야 한다 ${ }^{[4]}$. 또한 검사실 내의 공간산란선 분포는 방사선작업종사 자 및 환자에 대하여 피폭 정도의 지표로도 이용되고 있으며 ${ }^{[5]}$ 피폭 정도를 고려하기 위해서는 공간산란선 분포를 정확하게 파악하고, 공간산란선이 방호복에 얼 마나 차폐되는지를 정확하게 파악할 필요성이 있다. 이에 본 연구에서는 $\mathrm{X}$ 선 촬영실 내의 테이블 주변에 서 거리 및 각도 변화에 따른 공간산란선량 값을 측정 하고 ${ }^{[1]}$ 이를 바탕으로 하여 방호복 유무 시 거리, 가로 면 각도 및 높이변화에 따른 공간산란선량을 측정하 여 방사선작업종사자와 주변인 그리고 검사를 받게 되는 환자에 대한 피폭선량감소와 방호복 착용을 통 한 방사선방어의 중요성에 대해 알아보고자 한다.

\section{II. 재료 및 방법}

\section{1. 실험 기기}

1) 엑스선 촬영장치 :

(1) Controller ( DK II-525R/F in R/F X-ray System )

(2) Tube supports in X-rays Support. ( Model - SF 80 )

(3) Collimator ( Model - BL -50, Beam limiting Device)

2) 피사체(phantom)

: Chest Phantom ( RS111 ,Fluke Biomedical LLC )

3) 피사체(Apron)

: Medical X-ray protective APRON ( Model-Buckle B-Type $(0.5 \mathrm{mmPb})$, JPI )

4) 이온 챔버(Ionization chamber)

: Ionization chamber( 20X6-60E ) \& ( 20X6-1800 ) Probe [Radcal] 


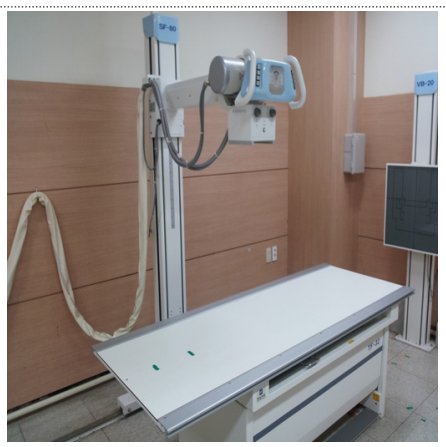

X-ray 촬영장치 (Model - SF 80)

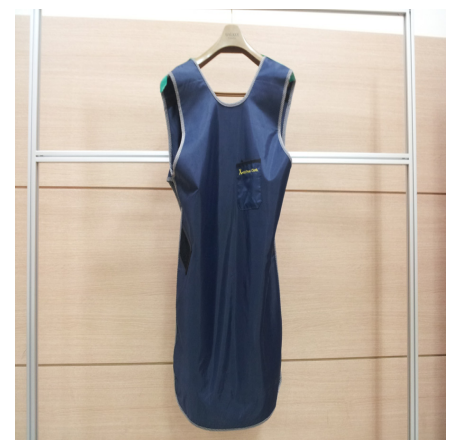

X-ray protective APRON (Buckle B-Type)

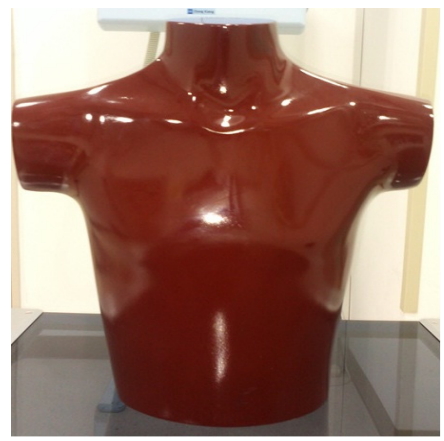

Chest Phantom (RS111)

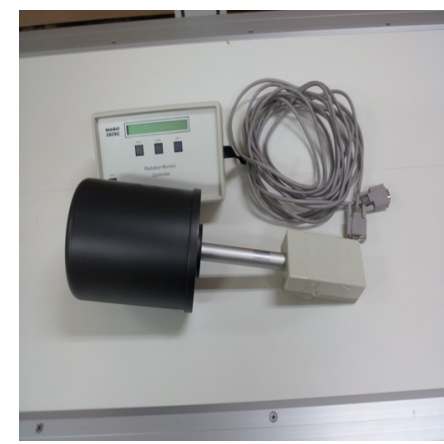

Ionization chamber (20X6-60E \& 20X6-1800)

\section{2. 실험 방법}

1) 측정 조건

(1) 촬영실 테이블 주변의 공간 산란 선량 분포 측정 조건.

(a) SID : $100 \mathrm{~cm}$

(b) 이온 챔버의 위치: 조사야 기준으로 주변 $50 \mathrm{~cm}, 70 \mathrm{~cm}$

(c) 측정 각도

(a) Horizontal 분포 : $180^{\circ}, 135^{\circ}, 90^{\circ}, 45^{\circ}, 0^{\circ},-45^{\circ},-90^{\circ},-135^{\circ}$

(b) Vertical 분포 1): $120^{\circ}, 90^{\circ}, 60^{\circ}, 30^{\circ}, 0^{\circ},-30^{\circ},-60^{\circ},-90^{\circ},-120^{\circ}$

(C) Vertical 분포 2): $120^{\circ}, 90^{\circ}, 60^{\circ}, 30^{\circ}, 0^{\circ},-30^{\circ},-60^{\circ},-90^{\circ},-120^{\circ}$

(2) 방호복 유무 측정에 따른 기하학적 조건

(a) 초점과 피사체 하단 사이의 거리 : $100 \mathrm{~cm}$

(b) 방호복의 위치 : 조사야 중심을 기준으로 $50 \mathrm{~cm}, 70 \mathrm{~cm}, 180 \mathrm{~cm}$

(c) 이온 챔버의 위치

(a) 조사야 중심을 기준으로 $70 \mathrm{~cm}, 90 \mathrm{~cm}, 200 \mathrm{~cm}$

(b) 바닥으로부터 $85 \mathrm{~cm}, 138 \mathrm{~cm}$

(C) Angle : $-90^{\circ},-45^{\circ}, 0^{\circ}, 45^{\circ}, 90^{\circ}$

(3) 조사 조건

(a) 고정 인자

- 관전압, 관전류 및 조사시간 : $80 \mathrm{kV}, 200 \mathrm{~mA}, 0.1 \mathrm{sec}$

- 피사체 두께 : $24 \mathrm{~cm}$

- 조사면 : $30 \times 30 \mathrm{~cm}^{2}$

(b) 변동 인자

- 방호복의 납당량 : $0 \mathrm{mmPb}, 0.5 \mathrm{mmPb}$

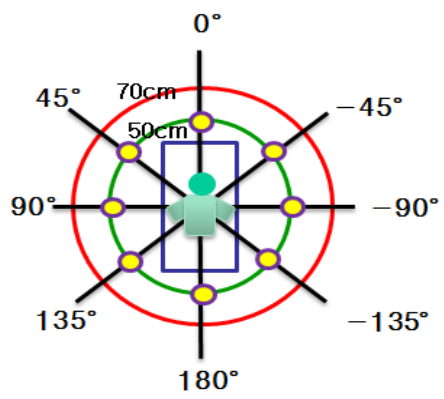

Fig. 1 Materials and Methods 

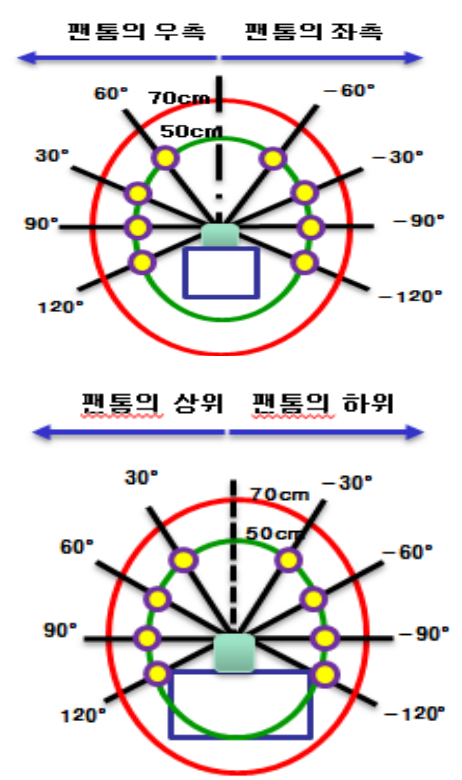

Fig 2. This picture shows the Horizontal \& vertical plane of Spatial Scattering radiation

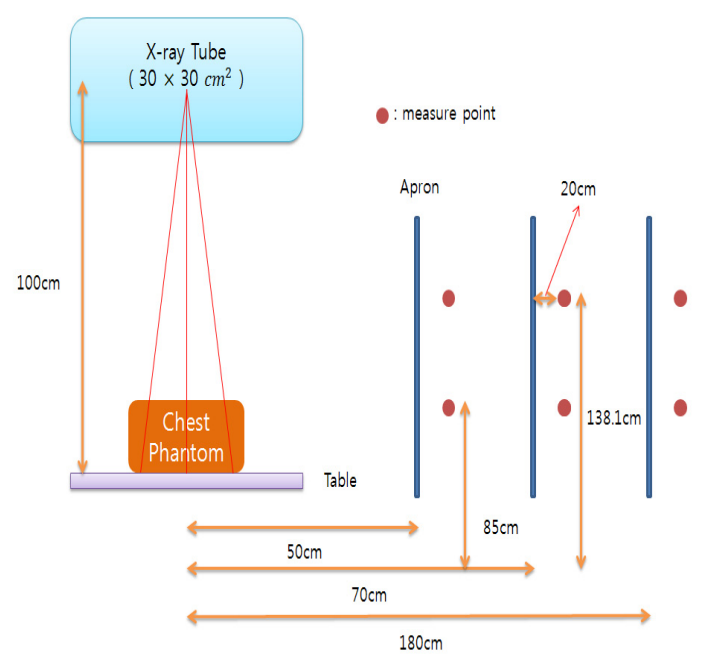

Fig. 3 This picture shows the vertical plane of measure point

\section{2)측정 방법}

(1) Horizontal plan \& Vertical plan 공간 산란선 측정

본 연구에서는 방호복 위치에 따른 공간 산란선 측 정을 시행하기에 앞서 Table 주변의 공간 산란선 분포
정도를 알아보기 위해 이온 챔버(20X6-60E \& 20X6-1800)를 이용하여 측정 하였다. 측정은 Horizontal, Vertical 두 가지 방향으로 구분하여 측정하였다.

Horizontal plan 측정은 장비의 높이 변화 없이 흉부 촬영용 팬톰과 동일한 높이에서 Horizontal 방향으로 팬톰 주위 4 분면에 대한 공간 산란선을 측정하였다. 측정 거리는 $50 \mathrm{~cm}, 70 \mathrm{~cm}$ 및 $45^{\circ}$ 각도 간격으로 변화시 켰으며, 각각 3 회씩 측정 하였다.

Vertical 공간 산란 측정은 팬톰 주변에 산란 선량을 측정할 위치를 선정하고 높이에 따른 각도 변화를 이 용하여 공간 산란 측정이며, 팬톰 주위의 4 분면에 $50 \mathrm{~cm}, 70 \mathrm{~cm}$ 로 거리변화를 주는 동시에 팬톰을 기준으 로 $-120^{\circ}$ 에서 $+120^{\circ}$ 까지 $30^{\circ}$ 각도변화에 따라 측정 장비를 위치시키고 각각의 지점에서 3 회씩 공간 산란 선량을 측정 하였다.

\section{(2) 방호복 위치에 따른 공간 산란선 측정}

이온 챔버(20X6-60E \& 20X6-1800)를 이용하여 촬영 체위와 촬영 조건은 임상에서 성인의 흉부 촬영시 사 용하는 조건으로 관전압 및 관전류, 조사시간을 설정 하였다. 보호자의 연령은 20 세 남성으로 가정하였고 평균 신장은 20 대 남성의 평균 체형인 사각체형의 신 장 $173.2 \mathrm{~cm}$ 로 설정하였다 ${ }^{[1]}$. 방호복의 위치는 보호자의 위치를 고려하여 조사야 중심으로부터 가로면으로 $50 \mathrm{~cm}, 70 \mathrm{~cm}, 180 \mathrm{~cm}$ 로 설정하였고 선량 측정 위치는 방 호복의 $20 \mathrm{~cm}$ 후방에서 측정하였다. 측정 위치의 높이 는 남성의 생식샘과 액와 림프절를 고려하여 각 각 바 닥으로부터 $85 \mathrm{~cm}, 138 \mathrm{~cm}$ 의 높이로 위치를 설정하였다 (Fig. 2). 촬영은 흥부 전후 방향 촬영으로 $\mathrm{X}$-선을 조사 함과 동시에 이온 챔버의 위치를 변화시키면서 선량 을 3 회씩 측정하였다. 측정된 선량 값은 다음과 같은 수식으로 공간산란선량을 계산하였다. 이온 챔버를 이 용하여 측정 시 실내의 기압 및 온도는 $868 \mathrm{mmHg}, 2$ $2{ }^{\circ} \mathrm{C}$ 였으며, 이 값을 이용하여 계산한 결과 교정상수 값은 1.05 였다.

(1) 공간산란선량 $(\mathrm{uSv}):$ 공간산란선량 $(\mathrm{uSv})=\left\{\sum[\right.$ (측정 선량 $) \times($ 교정상수 $)] /($ 측정 횟수 $)\}$

그리고 계산된 공간산란선량 값을 이용하여 방호 
복의 유무에 따른 공간산란선량 차이를 계산하였으며, 방호복 사용시 공간 산란선에 대한 차폐율을 알아보 고자 다음과 같은 수식을 이용하여 계산하였다.

(2) 차폐율 $(\%)=\{[$ ( 방호복 사용 전의 선량 $)-($ 방호복 사용 후의 선량 ) ] / 방호복 사용 전의 선량 $\} \times 100$

실험 전에 관전압의 정확성 범위는 실험 장비는 약 $\pm 7 \%$ 이내였으며, 조사선량 직선성은 변동계수 $(\mathrm{CV})$ 가 약 0.03 정도 됨을 확인하였다. 가슴 전후 방향 촬영을 정해진 위치에서 3 번씩 측정하여 평균치를 구하였고, $\mathrm{X}$ 선관의 관 부하를 가만하여 1 분 간격으로 $\mathrm{X}$ 선을 조 사하였다.

\section{III 연구결과}

\section{Horizontal plan과 Vertical plan 공간산란선량 측정.}

\section{1) Horizontal plan}

팬톰에 입사되는 beam의 중심과 팬톰 깊이의 중심 이 교차하는 지점을 각도와 거리를 측정하는 기준으
로 설정 하였다. 음극 측의 $90^{\circ},-90^{\circ}$ 의 측정 선량 값이 $50 \mathrm{~cm}$ 지점에서 $7.76 \mu \mathrm{Sv}, 3.66 \mu \mathrm{Sv}$ 으로 가장 높았으며, $70 \mathrm{~cm}$ 지점에서는 $7.74 \mu \mathrm{Sv}, 3.63 \mu \mathrm{Sv}$ 으로 공간 산란선량 값이 높았다.

\section{2) Vertical plan(1)}

팬톰에 입사되는 beam의 중심과 팬톰 깊이의 중심 이 교차하는 지점을 각도와 거리를 측정하는 기준으 로 설정하였다. $50 \mathrm{~cm}, 70 \mathrm{~cm}$ 거리에서 결과 팬톰의 우 측 $+60^{\circ}$ 공간 선량 값이 $21.94 \mu \mathrm{Sv}, 12.79 \mu \mathrm{Sv}$ 로 높은 값 을 보였으며, 팬톰 좌측 $-60^{\circ}$ 에서는 $30.03 \mu \mathrm{Sv}, 14.44 \mu$ $\mathrm{Sv}$ 로 공간 선량 값이 높게 나타났다.

\section{3) Vertical plan(2)}

팬톰에 입사되는 beam의 중심 지점과 팬톰 깊이의 중심이 교차하는 지점을 각도 및 거리를 측정하는 기 준으로 설정하였다. 그 결과 $50 \mathrm{~cm}, 70 \mathrm{~cm}$ 거리에서 결 과 팬톰의 우측 $+60^{\circ}$ 공간 선량 값이 $19.18 \mu \mathrm{Sv}, 9.82 \mu \mathrm{Sv}$ 로 높은 값을 보였으며, 팬톰 좌측 $-30^{\circ}$ 에서는 $20.25 \mu$ $\mathrm{Sv}, 8.02 \mu \mathrm{Sv}_{\mathrm{v}}$ 로 공간 선량 값이 높게 나타났다.

Table 1. Measured Spatial Scattering dose in Chest AP Radiography

\begin{tabular}{|c|c|c|c|c|c|c|c|c|}
\hline \multicolumn{9}{|c|}{ Hor izontal plan } \\
\hline 거리 각도 & $\begin{array}{c}0^{\circ} \\
\text { (팬톰 상부) }\end{array}$ & $+45^{\circ}$ & $+90^{\circ}$ & $135^{\circ}$ & $-45^{\circ}$ & $-90^{\circ}$ & $-135^{\circ}$ & $\begin{array}{c}180^{\circ} \\
\text { (팬톰 하부) }\end{array}$ \\
\hline $50 \mathrm{~cm}$ & $7.62 \mu \mathrm{Sv}$ & $6.55 \mu \mathrm{Sv}$ & $7.76 \mu S v$ & $7.30 \mu \mathrm{Sv}$ & $7.21 \mu \mathrm{Sv}$ & $7.74 \mu \mathrm{Sv}$ & $6.43 \mu \mathrm{Sv}$ & $5.96 \mu \mathrm{Sv}$ \\
\hline $70 \mathrm{~cm}$ & $4.45 \mu \mathrm{Sv}$ & $3.40 \mu \mathrm{Sv}$ & $3.66 \mu S v$ & $3.66 \mu \mathrm{Sv}$ & $3.66 \mu \mathrm{Sv}$ & $3.63 \mu \mathrm{Sv}$ & $3.26 \mu \mathrm{Sv}$ & $3.62 \mu \mathrm{Sv}$ \\
\hline \multicolumn{9}{|c|}{ Vertical plan(1) } \\
\hline 각도 & $\begin{array}{c}+120^{\circ} \\
\text { (팬톰 우측) }\end{array}$ & $+90^{\circ}$ & $+60^{\circ}$ & $+30^{\circ}$ & $-30^{\circ}$ & $-60^{\circ}$ & $-90^{\circ}$ & $\begin{array}{c}-120^{\circ} \\
\text { (팬톰 좌측) }\end{array}$ \\
\hline $50 \mathrm{~cm}$ & $4.76 \mu \mathrm{Sv}$ & $8.10 \mu \mathrm{Sv}$ & $21.94 \mu \mathrm{Sv}$ & $11.99 \mu \mathrm{Sv}$ & $16.49 \mu \mathrm{Sv}$ & $30.03 \mu \mathrm{Sv}$ & $10.01 \mu S v$ & $2.66 \mu \mathrm{Sv}$ \\
\hline $70 \mathrm{~cm}$ & $3.52 \mu \mathrm{Sv}$ & $5.10 \mu \mathrm{Sv}$ & $12.79 \mu \mathrm{Sv}$ & $9.18 \mu \mathrm{Sv}$ & $11.15 \mu \mathrm{Sv}$ & $14.44 \mu \mathrm{Sv}$ & $7.15 \mu \mathrm{Sv}$ & $1.28 \mu \mathrm{Sv}$ \\
\hline \multicolumn{9}{|c|}{ Vertical plan(2) } \\
\hline 거리 & $\begin{array}{c}+120^{\circ} \\
\text { (팬톰 상위) }\end{array}$ & $+90^{\circ}$ & $+60^{\circ}$ & $+30^{\circ}$ & $-30^{\circ}$ & $-60^{\circ}$ & $-90^{\circ}$ & $\begin{array}{c}-120^{\circ} \\
\text { (팬톰 하위) }\end{array}$ \\
\hline $50 \mathrm{~cm}$ & $5.25 \mu \mathrm{Sv}$ & $9.50 \mu \mathrm{Sv}$ & $19.18 \mu \mathrm{SV}$ & $18.49 \mu \mathrm{Sv}$ & $11.87 \mu \mathrm{Sv}$ & $20.25 \mu \mathrm{Sv}$ & $7.11 \mu \mathrm{Sv}$ & $3.53 \mu \mathrm{Sv}$ \\
\hline $70 \mathrm{~cm}$ & $3.45 \mu \mathrm{Sv}$ & $5.33 \mu \mathrm{Sv}$ & $9.82 \mu S v$ & $8.72 \mu \mathrm{Sv}$ & $5.55 \mu \mathrm{Sv}$ & $8.02 \mu \mathrm{Sv}$ & $3.74 \mu \mathrm{Sv}$ & $2.89 \mu \mathrm{Sv}$ \\
\hline
\end{tabular}




\section{2. 방호복 위치에 따른 공간산란 선량 측정}

\section{1) 방호복 착용 유무에 따른 생식샘에서의 공간산란선량}

\section{(1) 방호복을 착용하지 않았을 경우의 공간산란선량}

가슴 전후 방향 촬영 시 조사야 중심으로부터 각도 에 따라 생식샘의 공간산란선량을 측정한 결과는 다 음과 같다. 조사야 중심으로부터 $70 \mathrm{~cm}$ 거리에서는 각 도에 따라 각 각 $4.45 \mu \mathrm{Sv}, 3.66 \mu \mathrm{Sv}, 4.13 \mu \mathrm{Sv}, 3.40 \mu \mathrm{Sv}, 3.63$ $\mu S_{\mathrm{v}}$ 였으며, $20 \mathrm{~cm}$ 거리 증가시 각도에 따라 $3.27 \mu \mathrm{Sv}_{\mathrm{v}}$,
$2.84 \mu \mathrm{Sv}, 2.38 \mu \mathrm{Sv}, 2.48 \mu \mathrm{Sv}, 2.11 \mu \mathrm{Sv}$ 정도로 줄어들었다. $200 \mathrm{~cm}$ 에서 측정한 결과 각도에 따라 $0.51 \mu \mathrm{Sv}, 0.56 \mu \mathrm{Sv}$, $0.56 \mu \mathrm{Sv}, 0.54 \mu \mathrm{Sv}, 0.46 \mu \mathrm{Sv}_{\mathrm{v}}$ 로 측정되었다.

\section{(2) 방호복을 착용하였을 경우의 공간산란선량}

조사야 중심으로부터 $70 \mathrm{~cm}$ 거리에서는 각도에 따라 각 각 $0.12 \mu \mathrm{Sv}_{\mathrm{v}}, 0.11 \mu \mathrm{Sv}, 0.11 \mu \mathrm{Sv}, 0.08 \mu \mathrm{Sv}, 0.11 \mu \mathrm{Sv}_{\mathrm{v}}$ 였으며, $20 \mathrm{~cm}$ 거리 증가시 각도에 따라 각 각 $0.11 \mu \mathrm{Sv}, 0.06 \mathrm{\mu Sv}$, $0.09 \mu \mathrm{Sv}_{\mathrm{v}}, 0.07 \mu \mathrm{Sv}_{\mathrm{v}}, 0.08 \mu \mathrm{Sv}_{\mathrm{v}}$ 정도로 줄어들었다. $200 \mathrm{~cm}$ 에 서 측정한 경우에는 각도에 따라 $0.03 \mu \mathrm{Sv}, 0.02 \mu \mathrm{Sv}, 0.03$ $\mu S_{v}, 0.03 \mu S_{v}, 0.04 \mu S_{v}$ 로 측정되었다.

Table 2. Measured Spatial Scattering dose in Chest AP Radiography

\begin{tabular}{|c|c|c|c|c|c|c|c|}
\hline 측정 위치 & $\begin{array}{c}\text { 방호복의 } \\
\text { 납당량 } \\
(\mathrm{mmPb})\end{array}$ & & $0^{\circ}$ & $45^{\circ}$ & $90^{\circ}$ & $135^{\circ}$ & $180^{\circ}$ \\
\hline \multirow{6}{*}{$\begin{array}{l}\text { 생식샘 } \\
(85 \mathrm{~cm})\end{array}$} & \multirow{3}{*}{0} & $70 \mathrm{~cm}$ & $4.45 \mu \mathrm{SV}$ & $3.66 \mu \mathrm{Sv}$ & $4.13 \mu \mathrm{Sv}$ & $3.40 \mu \mathrm{Sv}$ & $3.63 \mu \mathrm{Sv}$ \\
\hline & & $90 \mathrm{~cm}$ & $3.27 \mu \mathrm{SV}$ & $2.84 \mu S v$ & $2.38 \mu \mathrm{SV}$ & $2.48 \mu \mathrm{Sv}$ & $2.11 \mu \mathrm{Sv}$ \\
\hline & & $200 \mathrm{~cm}$ & $0.51 \mu \mathrm{Sv}$ & $0.56 \mu S v$ & $0.56 \mu S v$ & $0.54 \mu \mathrm{Sv}$ & $0.46 \mu S v$ \\
\hline & \multirow{3}{*}{0.5} & $70 \mathrm{~cm}$ & $0.12 \mu \mathrm{SV}$ & $0.11 \mu S v$ & $0.11 \mu \mathrm{Sv}$ & $0.08 \mu \mathrm{Sv}$ & $0.11 \mu \mathrm{Sv}$ \\
\hline & & $90 \mathrm{~cm}$ & $0.11 \mu \mathrm{SV}$ & $0.06 \mu \mathrm{Sv}$ & $0.09 \mu \mathrm{Sv}$ & $0.07 \mu \mathrm{Sv}$ & $0.08 \mu \mathrm{Sv}$ \\
\hline & & $200 \mathrm{~cm}$ & $0.03 \mu \mathrm{Sv}$ & $0.02 \mu S v$ & $0.03 \mu \mathrm{Sv}$ & $0.03 \mu \mathrm{Sv}$ & $0.04 \mu \mathrm{Sv}$ \\
\hline \multirow{6}{*}{$\begin{array}{c}\text { 액와림프절 } \\
\text { (138cm) }\end{array}$} & \multirow{3}{*}{0} & $70 \mathrm{~cm}$ & $5.77 \mu \mathrm{Sv}$ & $6.13 \mu \mathrm{Sv}$ & $6.03 \mu \mathrm{Sv}$ & $5.04 \mu \mathrm{Sv}$ & $4.86 \mu \mathrm{Sv}$ \\
\hline & & $90 \mathrm{~cm}$ & $3.85 \mu \mathrm{Sv}$ & $3.83 \mu \mathrm{Sv}$ & $3.36 \mu \mathrm{Sv}$ & $3.08 \mu \mathrm{Sv}$ & $2.65 \mu \mathrm{Sv}$ \\
\hline & & $200 \mathrm{~cm}$ & $0.75 \mu \mathrm{Sv}$ & $0.74 \mu \mathrm{Sv}$ & $0.72 \mu \mathrm{Sv}$ & $0.58 \mu \mathrm{Sv}$ & $0.56 \mu \mathrm{Sv}$ \\
\hline & \multirow{3}{*}{0.5} & $70 \mathrm{~cm}$ & $0.15 \mu \mathrm{Sv}$ & $0.14 \mu S v$ & $0.16 \mu \mathrm{Sv}$ & $0.16 \mu \mathrm{Sv}$ & $0.18 \mu \mathrm{Sv}$ \\
\hline & & $90 \mathrm{~cm}$ & $0.13 \mu \mathrm{Sv}$ & $0.13 \mu \mathrm{Sv}$ & $0.11 \mu \mathrm{Sv}$ & $0.13 \mu \mathrm{Sv}$ & $0.14 \mu \mathrm{Sv}$ \\
\hline & & $200 \mathrm{~cm}$ & $0.06 \mu \mathrm{Sv}$ & $0.04 \mu \mathrm{Sv}$ & $0.05 \mu \mathrm{Sv}$ & $0.05 \mu \mathrm{Sv}$ & $0.06 \mu \mathrm{Sv}$ \\
\hline
\end{tabular}

\section{2) 방호복 착용 유무에 따른 액와림프절에서의 공간산란선량}

\section{(1) 방호복을 착용하지 않았을 경우의 공간산란선량}

가슴 전후 방향 촬영 시 조사야 중심으로부터 어깨 높이에 따른 각도별 공간산란선량을 측정한 결과는 다음과 같다. 조사야 중심으로부터 $70 \mathrm{~cm}$ 거리에서는 각도에 따라 각각 $5.77 \mu \mathrm{Sv}, 6.13 \mu \mathrm{Sv}, 6.03 \mu \mathrm{Sv}, 5.04 \mathrm{\mu Sv}$, $4.86 \mathrm{\mu Sv}$ 이었다. $20 \mathrm{~cm}$ 거리를 변화시킨 후 측정 결과는 각각 $3.85 \mu \mathrm{Sv}, 3.83 \mu \mathrm{Sv}, 3.36 \mu \mathrm{Sv}, 3.08 \mu \mathrm{Sv}, 2.65 \mu \mathrm{Sv}$ 정도로
줄어들었다. $200 \mathrm{~cm}$ 거리에서는 $0.75 \mu \mathrm{Sv}, 0.74 \mu \mathrm{Sv}, 0.72 \mu$ $\mathrm{Sv}, 0.58 \mu \mathrm{Sv}, 0.56 \mu \mathrm{Sv}_{\mathrm{v}}$ 로 측정되었다.

\section{(2) 방호복을 착용하였을 경우의 공간산란선량}

조사야 중심으로부터 $70 \mathrm{~cm}$ 거리에서는 각도에 따라 각 각 $0.15 \mu \mathrm{Sv}, 0.14 \mathrm{\mu Sv}, 0.16 \mathrm{\mu Sv}, 0.16 \mathrm{\mu Sv}, 0.18 \mu \mathrm{Sv}_{\mathrm{v}}$ 였으 며, $20 \mathrm{~cm}$ 거리 변화시 측정 결과는 $0.13 \mu \mathrm{Sv}, 0.13 \mu \mathrm{Sv}$, $0.11 \mu \mathrm{Sv}_{\mathrm{v}}, 0.13 \mu \mathrm{Sv}, 0.14 \mu \mathrm{Sv}$ 로 값이 줄어들었다. $200 \mathrm{~cm}$ 에 서는 각도에 따라 $0.06 \mu \mathrm{Sv}, 0.04 \mu \mathrm{Sv}, 0.05 \mu \mathrm{Sv}, 0.05 \mu \mathrm{Sv}$, $0.06 \mu \mathrm{Sv}$ 로 측정되었다. 


\section{IV. 고찰 및 결론}

본 연구에서는 방호복 착용 유무에 따른 생식샘과 액와 림프절 공간산란선량을 측정하였다. 부위별 공간 산란선량을 측정하기에 앞서 촬영실 내의 공간산란선 량을 측정하였으며, 그 결과 촬영실 내의 Table 주변의 공간산란선 분포는Horizontal $+90^{\circ},-90^{\circ}$ 지점에서 $3.63 \mu$ $\mathrm{Sv}_{\mathrm{v}} 7.76 \mu \mathrm{Sv}_{\mathrm{v}}$ 의 분포를 보였다. 또한 $\operatorname{Vertical}(1)$ 측정에서 는 $+60^{\circ},-60^{\circ}$ 각도에서 $12.79 \mu \mathrm{Sv}_{\mathrm{v}} \sim 30.03 \mu \mathrm{Sv}$ 의 분포를 보 였고, $\operatorname{Vertical}(2)$ 측정에서는 $+60^{\circ},-60^{\circ}$ 각도에서 $8.02 \mu$ $\mathrm{S}_{\mathrm{v}} \sim 19.18 \mu \mathrm{Sv}$ 의 분포를 보였다. 측정 결과 값으로 보아 Tube의 음극 측과 촬영실의 벽면 측에 가까울수록 공 간산란선량이 증가함을 알 수 있었다. 또한 거리 증가 시 수평 분포에서는 거리 역자승의 법칙에 따라 선량 값이 감소하는 결과 값을 나타냈으며, 수직 분포에서 는 주로 $60^{\circ},-60^{\circ}$ 분포에서 선량 값이 가장 높게 측정 된 것으로 보아 안구 방향으로의 산란선량이 증가함 을 확인 하였고 그에 대한 방호가 필요할 것으로 사료 된다. 이러한 결과 값은 다른 논문지에 개제되어 있는 바와 같이 거리에 따른 공간 산란선의 평균값은 수평 분포의 평균 값 보다 수직 분포의 평균값이 다소 높게 나타났다 ${ }^{[1]}$. 또한 은 ${ }^{[7]}$ 의 연구 결과에서 산란선량의 위 치가 바닥에서 높이가 높아질수록 산란선량이 감소함 을 보였다는 결과와는 달리 본 연구에서는 높이가 증 가 할수록 공간산란선량의 값이 증가함을 확인하였다.

위의 결과 값을 바탕으로 방호복 착용 유무 시 테이 블 주변에 발생하는 공간산란선량을 거리, 각도 및 위 치에 따라 측정하여 방호복 착용의 중요성을 확인한 결과 방호복을 착용하지 않았을 경우 생식샘의 위치 인 $85 \mathrm{~cm}$ 에서는 가로면 거리 $70 \mathrm{~cm}$ 일 때 각도에 따라 $3.40 \mu \mathrm{Sv}_{\mathrm{v}} \sim 4.45 \mu \mathrm{Sv}_{\mathrm{v}}$ 정도 피폭 받는 것으로 측정되었고, 액와 림프절 위치인 $138 \mathrm{~cm}$ 에서는 $4.86 \mu \mathrm{Sv}_{\mathrm{v}} \sim 6.13 \mu \mathrm{Sv}_{\mathrm{v}}$ 정 도 피폭 받는 것으로 측정되었다. 이러한 측정 결과 값으로 보아 앞서 측정한 공간산란선량과 유사하게 테이블에서 높이 변화에 따른 공간산란선량의 영향이 있는 것으로 사료되며, 방호복 유무에 따라 적기는 10 배에서 많게는 45 배 정도 차이가 나타남을 확인하였 다. 또한 방호복 차폐율 계산 결과는 거리, 각도, 위치 에 따라 $89.7 \% \sim 97.8 \%$ 차폐가 가능한 것으로 계산되
었으며, 즉 거리, 각도 위치에 관계없이 $89.7 \%$ 이상의 차폐를 할 수 있음을 확인할 수 있었다.

국내에서는 국민의 삶의 질 향상과 더불어 건강 증 진에 대한 관심이 높아짐에 따라 진단 방사선 분야에 서 건강 검진 등의 $\mathrm{X}$ 선 검사 횟수가 증가하고 있는 추 세이며, 이러한 검사로 인해 인공 방사선에 의한 피폭 이 방사선 피폭의 약 $90 \%$ 를 차지하고 있으므로 환자 또는 방사선 작업 종사자, 보호자의 직접, 간접적인 피 폭선량 감소를 위한 저감화가 반드시 필요하다 ${ }^{[6]}$. 환 자의 질병 진단을 위하여 방사선 검사를 받는 것은 방 사선에 의해 발생할 수 있는 위해보다 얻어지는 이익 이 더 크기 때문이며, 방사선 노출 주변의 환자 및 보 호자, 방사선 작업 종사자의 피폭을 저감화 하기 위해 서는 ${ }^{[1]}$ 방사선 촬영 시에는 반드시 방호복을 착용하는 것이 바람직하다. 더불어 수평 분포와 수직 분포에서 공간산란 선량을 측정한 결과 수직 분포에 따른 공간 산란선량이 증가되므로 상대적으로 차폐하기 용이하 지 않은 갑상선 및 안구 부위의 차폐 또한 고려하여야 한다. 그러므로 방사선작업종사자는 방사선 검사시 방 호복착용의 불편함 때문에 발생하는 방어에 대한 소 홀함을 인식하고, 특정장기의 방어에도 관심을 갖고 실천하여야 할 것으로 판단된다. 그리고 환자 검사시 검사부위를 제외한 특정장기의 피폭선량감소에도 관 심을 갖고 접근하여야 하며, 방사선 검사시 거동이 불 편한 환자를 보조하게 되는 보호자에 대한 전면 방호 복 착용은 물론 갑상선 보호대와 납안경 착용 등을 의 무화하여 촬영실 내에서 이루어지는 생식선차폐 뿐만 아니라, 갑상선과 안구에 대한 방사선피폭의 저감화 에도 노력을 기울여, 최소한의 피폭선량으로 진단가치 가 높은 의료영상물을 제공하는데 본 연구가 도움이 되었으면 한다.

\section{감사의 글}

이 논문은 2011년도 정부(교육과학기술부)의 재원으 로 한국연구재단-일반연구자 협동연구지원사업의 지 원을 받아 수행된 연구임(No. 2011-0027312). 


\section{Reference}

[1] 김성규, “영상의학과 이동 검사 영역의 공간선량 분포에 대한 측정 및 분석”, 대한 디지털 의료영상학회논문지, Vol. 11, No. 1, p.5, 2009.

[2] 송종순, "방사선 방어의 최적화 절차론 개발에 관한 연구", 방사선방어학회지, Vol. 19, No. 1, p.1, 1994.

[3] 식품의약품안정청, "방사선관계종사자의 직업적 피폭에 따른 건강영향평가 연구", 2008.

[4] 권덕문, "이동형 $\mathrm{X}$ 선 촬영에서 공간산란선량 분포 측정" 대한 방사선 기술학회지, Vol 24, No. 1, 2001. p.23, 2001.

[5] 김선철, "양방사선 골밀도 측정 장치의 공간산란선량분포 측정”, 대한 디지털 의료영상학회논문지, Vol. 13, No .2, p.7, 2011.

[6] 식품의약 안전청 “환자선량 측정 가이드라인”, 12, 2007.

[7] 은성종, " $\mathrm{X}$ 선 촬영시 테이블 주변 촬영도움자의 피폭선량 측정” 한국방사선학회논문지 Vol. 5, No. 6, p.419, 2011. 